\title{
South Africa After Apartheid
}

\author{
African National Congress $\uparrow$
}

\section{Introduction}

Today South Africa is in flames; the fires of liberation are engulfing the whole country. Politically and economically the apartheid regime is in a deep crisis. The structures of apartheid are crumbling. The ANC called on the people to render the country ungovernable. This is exactly what the people are doing. What we are saying is that the future of the South African revolution and our movement does not depend on abstract hopes and wishes-our ideals and aspirations will become a reality as a result of our actions and thinking today. An analysis of a post-apartheid society can only be meaningful if it takes into account the reality of today.

Starting in 1984, the apartheid regime appears to have banked on two strategies in its efforts to shape the political landscape in South Africa. The government hoped the Nkomati Accord ${ }^{1}$ and the new constitution ${ }^{2}$ would destroy the ANC and the democratic movement in our country. Neither of these strategies had their intended effects. The Nkomati Accord, we were told, would put a halt to the armed struggle being waged by the ANC inside South Africa by denying it support facilities inside Mozambique. Nothing of that sort happened. ANC activity inside South Africa increased. It proved much too deeply rooted in the South African people to be suppressed. The cynical constitutional innovations actually backfired on the regime. The new constitutional arrangements were supposed to introduce some form of "power sharing" between the Whites, Indians, and Coloureds, with the Indians and Coloureds being "junior partners." Instead, the effort to co-opt has only bred increased resentment and opposition among Africans, as well as the chosen junior partners.

$\dagger$ This official response from the African National Congress was authored by Francis Meli. Mr. Meli is Editor of Sechaba, official organ of the African National Congress, and Member, ANC National Executive Committee.

1. The Nkomati Accord was an "Agreement of Non-Aggression" between South Africa and Mozambique, and was signed on March 16, 1984. See 23 I.L.M. 282 (1984). The Nkomati Accord envisioned a quid pro quo: Mozambique would refrain from giving support to the ANC, and South Africa would refrain from giving support to the Mozambique National Resistance Movement.

2. Republic of South Africa Constitution Act of 1983, inaugurated Sept. 3, 1984. See N.Y. Times, Sept. 4, 1984, at A1, col. 5. 
There has been no interracial cooperation. Resistance, especially African resistance, has been on the ascendancy. Since September 1984-the time of the so-called elections-more than one thousand people have been murdered, mainly by the army and police. The situation has been so bad that one writer in Sechaba, the official organ of the ANC, exclaimed: "The moment of revolution is now or never in our lifetime."

\section{Our Strategy}

The enemy has reacted violently to these developments: proclamation of martial law, handing over administration of large areas of our country to the murderous army and police, the use of secret death squads, mass arrests, stringent control of the press, continuing external aggression, and the murder of our people. This is happening at a time when the economy is undergoing a deep crisis, with resultant entrenchment, unemployment, a galloping cost of living, and banishment to the bantustans and resettlement areas. The Whites are affected as well. White unemployment is increasing. Many conscripts return to civilian life without jobs and with no prospect of employment. Thousands of small and medium businesses have collapsed. Individual bankruptcies have multiplied without stop. Surely the apartheid system is in a crisis.

President Tambo, speaking on behalf of the National Executive Committee of the ANC, stated:

Completely unable to deal with [the] enormous general crisis, Botha has increasingly lost contact with reality. Illusions are taking the place of facts. The hollow dreams of a tyrant appear to him to be the very essence of policy. Botha relies on bombast and bluster to hide the fact that he is no more than a fleeting shadow on the world stage. ${ }^{3}$

What is the strategy of the ANC under these circumstances? President Tambo has already answered this question in the speech quoted above:

Our strategic goal must be to shift the balance of strength decisively in favor of our struggle, through the further ripening of the revolutionary situation beyond the point where the regime is not able to rule in the old way, to the stage where it is unable to govern. Thus, we must continue to make South Africa ungovernable and apartheid unworkable. In the attack we must aim further to weaken the Botha regime drastically, to sap its strength, to take away from it even the capacity to launch a limited counteroffensive. ${ }^{4}$

3. From a speech delivered in Lusaka, Zambia, on Jan. 8, 1986, to commemorate the 74th anniversary of the formation of the ANC.

4. Id. 
In actual practical political terms, this means the consolidation of the four pillars on which our revolutionary struggle rests. These are, first of all, the all-round vanguard activity of the underground structures of the ANC; second, the united mass actions of our people; third, our armed offensive spearheaded by Umkhonto we Sizwe (the Spear of the Nation); and fourth, the international drive to isolate the apartheid regime and win worldwide moral, political, and material support for the struggle. This entails support for the workers' demands, womens' protests and demonstrations, youth and students' struggles, and all other new organisational formations and new forms of struggle, including the creation of mass insurrectionary zones in many parts of our country. Unity of the democratic forces is our battle cry. The ANC is confronting the enemy squarely on all fronts: on the military field, in the churches, and in strikes, demonstrations, and school boycotts.

In the international arena we are working with the growing body of people and nations who recognize that the policies of the apartheid regime constitute a grave threat to international peace and global security. It must first of all be recognized that apartheid is an immediate problem for all the nations in the region. The recent strangulation of Lesotho is a case in point. 5 The frontline states are being destabilised through the activities of the Mozambique National Resistance, Savimbi's UNITA movement, and the Lesotho Liberation Army in Lesotho. The so-called "non-aggression pacts" with countries which are not interested in, nor have the capacity or capability of, attacking South Africa are part and parcel of the enemy strategy.

We are seeking the implementation of UN resolutions on sanctions, appealing to governments and non-governmental organizations to support our cause. We strive to transform the sympathies of pity into active solidarity. Solidarity is not pity and pity is not actually what we want. What we are saying is that solidarity with the people of South Africa is not helping "needy" and "poor" people. The South African people are fighting against colonialism and imperialism. They are dying and living to rid the world of this scourge. Their liberation will definitely contribute to the securing of world peace. Their battles are your battles. Solidarity is a two-way traffic.

The ANC is central to the solution of the South African crisis, not only because of its popularity and support amongst the people, but also because the ANC is the only organisation within South Africa that

5. See N.Y. Times, Jan. 21, 1986, at A3, col. 1. See also N.Y. Times, Feb. 2, 1986, at A9, col. 1 (seizure of South African exiles in Lesotho). 
engages the enemy militarily. Its military wing, Umkhonto we Sizwe (the Spear of the Nation), is composed of old and young men and women from all South African national groups. These people have joined the ANC army voluntarily. These are sons and daughters of our people; people who are motivated, and fighting for a cause. These are former stonethrowing Soweto students, survivors of the Uitenhage massacres, ${ }^{6}$ victims of the mass removals from the various "settlement areas" and bantustans. They form the nucleus of our people's army-the army that will defeat Botha's army.

Their armed operations also have a psychological impact. They instill self-confidence in the people, and transform the latent hostility of the people to the regime into open mass confrontation. They intensify the sense of unease and insecurity among the enemy forces, and they increase the conviction among the struggling people that victory is certain. These armed operations create the political and psychological climate that makes it easier for political and military organisers to organise within the country.

However, these developments should be no reason for complacency. The apartheid regime and its allies are on the offensive to liquidate the ANC, if not morally, then physically. They are devising scheme after scheme. The ANC is being "advised" to abandon armed struggle; it must "loosen" its ties with the Soviet Union, other socialist countries, and the South African Communist Party. The ANC must become part of the "reform process," and the ANC must become one amongst many organisations.

The problem with this "advice" is that it is being given at a time when the racist regime is killing our people left, right, and centre; when the U.S. and Britain are refusing to meet the ANC-because they regard it as a "terrorist organisation"; and when the ANC leaders are either in jail, murdered, or in exile. Ironically, these countries do receive representatives of the racist regime-the greatest terrorist in our region.

What these countries should be thinking about instead is the demand for more than just the formal end of martial law (called the "state of emergency"), the unbanning of the ANC and its allies (including the South African Communist Party), and the repeal of all pieces of legislation associated with the undemocratic practices of the Botha regime. We want one person, one vote. The unconditional release of Nelson Mandela and all other political prisoners is one of our demands. The return of all

6. Twenty blacks were shot and killed in March, 1985 at Uitenhage township. N.Y. Times, Mar. 22, 1985, at A1, col. 1 . 
those who were forced into exile is another. We demand the withdrawal of racist South African troops from Angola and the total, wholesale withdrawal of racist South Africa from Namibia. With regard to Namibia, it is important to note that apartheid is committing a double crime against the people of that country. Apartheid is both occupying Namibia and misusing it to attack the peace- and freedom-loving people of Angola.

\section{The Role of the ANC and the Freedom Charter}

The ANC has earned the right to speak for and on behalf of the people of South Africa. How can the ANC be one amongst many organisations when it has conquered in struggle the position of being the vanguard of the democratic revolution? When it has won the leadership of the democratic forces? When the Black masses look to the ANC to lead them? When its programme-the Freedom Charter-has become their programme?

The ANC is faced with the task of organising and leading all the nationally oppressed people-African, Coloured, and Indian-and to win over to its banner all democratically minded Whites. Today the ANC is a genuine people's organisation. It enjoys the support and confidence of the people whom it leads. The ANC is viewed by the masses of our people as the product of their sacrifices, as the heir and continuation of the revolutionary experience of the oppressed people as a whole, and as the people's organiser and leader. How can such an organisation be "one amongst many"?

The Freedom Charter is well known. ${ }^{7}$ We need to stress, however, that its preamble states that South Africa belongs to all who live in it, Black and White, and expresses both the non-racial and anti-racist policies of the ANC. In clear and unmistakable terms, it goes on:

[T]hat no government can justly claim authority unless it is based on the will of the people;

That our people have been robbed of their birthright to land, liberty and peace by a form of government founded on injustice and inequality;

That our country will never be prosperous or free until all our people live in brotherhood, enjoying equal rights and opportunities;

That only a democratic state, based on the will of all the people can secure to all their birthright without distinction of colour, race, sex or belief.

7. The Freedom Charter, adopted by the Congress of the People on June 26, 1955, is reproduced infra as an Appendix to this response. 
These objectives, the Freedom Charter states, will be realised through a struggle which obviously takes various forms.

Sechaba, the official organ of the ANC, explained the philosophy of the Freedom Charter in the following words:

The Freedom Charter lays a basis and is a precondition for further development and radicalisation of our revolution; its implementation will presuppose and demand the destruction of the White racist regime and the abolition of national, cultural, religious and language privileges of Whites or Blacks. This will encompass the equality of all ethnic groups-large or small, Black or White-and satisfaction of their national rights and feelings, traditions and customs, aspirations and emotions, characteristics and features and development of their languages and culture, interaction between different cultures and languages, and inter-ethnic contacts. This is what we mean by national self-determination. This entails the injection of hatred for the enemy and all that he stands for, imbuing the masses with a revolutionary consciousness and this should be accompanied by the stimulation of national pride and identity, assertiveness and patriotism which are associated with the revolutionary traditions of anti-colonialism and antiimperialism of all our people and ethnic groups and their positive contribution to the struggle for social progress. The solution of the national question in South Africa entails the . . . raising of the living standard of the Black majority to that of the Whites and then the general improvement and development in material life and cultural welfare of all the people irrespective of race, colour and creed, to an extent hitherto unknown in South Africa.

\section{Character Of The Struggle}

The character of the South African revolution takes the form of an anti-colonial and anti-imperialist struggle. It is anti-colonial because since 1652, when the colonists first invaded our country, South Africa has never been decolonised. Therefore, Botha and his ilk are the direct descendants of their colonialist predecessors. This does not mean that all the Whites are colonial in attitude. Some came from working-class backgrounds, such as those European workers who introduced socialist ideas and working class organisation in South Africa. Therefore, although not all Whites are colonisers, the present historic injustice of national oppression of Blacks by Whites is a product of colonial conquest.

When one considers the Western involvement in the economy of South Africa, the cultural ties, the sporting links, the militarisation of the Indian Ocean- e.g., Diego Garcia—and the diplomatic support apartheid is getting even at the UN, our struggle cannot but be anti-imperialist. The Freedom Charter says the rich mineral resources in the country shall be the property of the people. The mines, land, and other heavy industries shall be nationalised. These demands were repeated recently 
by COSATU at its inaugural conference. ${ }^{8}$ In other words, apartheid cannot be reformed-we want apartheid abolished. No tinkering with apartheid, or the removal of the so-called "hurtful aspects" of apartheid, will satisfy the Black masses of South Africa. Reagan's policy of "constructive engagement" ended up being "constructive marriage." The cornerstone of this constructive engagement policy is the Sullivan Principles and the EEC Code of Conduct. Nelson Mandela, as early as 1958, warned against American imperialism: "American imperialism is all the more dangerous because, having witnessed the resurgence of the people of Asia and Africa against imperialism and having seen the decline and fall of once powerful empires, it comes to Africa elaborately disguised."

Nelson Mandela has explained the character of our revolution. He says the Freedom Charter does not envisage placing power in the hands of one class, as the case is in a socialist revolution, but seeks to place power in the hands of the people. Our revolution will transfer power to a democratic class alliance. Mandela says:

The Charter is more than a mere list of demands for democratic reforms. It is a revolutionary document precisely because the changes it envisages cannot be won without breaking up the economic and political set-up of present South Africa.

Whilst the Charter proclaims democratic changes of a far-reaching nature, it is by no means a blueprint for a socialist state but a programme for the unification of various classes and groupings amongst the people on a democratic basis. Under socialism the workers hold state power. They and the peasants own the means of production, the land, the factories, and the mills. All production is for use and not for profit. The Charter does not contemplate such profound economic and political changes. Its declaration "The People Shall Govern!" visualizes the transfer of power not to any single social class but to all the people of this country, be they workers, peasants, professional men, or petty-bourgeoisie. ${ }^{10}$

Mandela goes on to say:

It is true that in demanding the nationalization of the banks, the gold mines, and the land, the Charter strikes a fatal blow at the financial and gold-mining monopolies and farming interests that have for centuries plundered the country and condemned its people to servitude. But such a step is imperative because the realization of the Charter is inconceiveable, in fact

8. The Congress of South Africa Trade Unions, the largest labor federation in South Africa's history, consists of roughly 500,000 workers and was formed on November 30, 1985. N.Y. Times, Dec. 1, 1985, at A1, col. 2; N.Y. Times, Dec. 2, 1985, at A., col. 1.

9. N. Mandela, The Struggle Is MY LifE 75 (1978).

10. Id. at 54,55 . 
impossible, unless and until these monopolies are smashed and the national wealth of the country turned over to the people. ${ }^{11}$

What this means is that the destruction of monopolies will lead to a democratisation of internal policy. This will break the grip of world imperialism on South Africa and lead to an independent policy of peace and friendship. South Africa must come out of the imperialist camp and join the community of freedom- and peace-loving people of the world. Indeed, only then shall South Africa, to quote the Freedom Charter, "be a fully independent state, which respects the rights and sovereignty of all nations." This is a recognition that South Africa is not yet a "fully independent state." South Africa could not be a "fully independent state" because, in 1910, when "independence" was granted to the White minority by Britain, the status of the Blacks did not change. There emerged a colonialism of a special type where the Africans were colonised not by London, but by Pretoria, with London pulling the strings from behind. In other words, in South Africa we are not dealing with the problem of changing South Africa's relations with a foreign nation outside our borders-although in a broader sense we are-as was the case in colonial Africa, including Mozambique, Angola, Zimbabwe, and Namibia. The internal economic and political rearrangements within South Africa, that is the destruction of the present state, will alter the status of the Black majority. The overthrow of oppression will introduce democracy in South Africa-therefore, the overthrow of the present regime in South Africa is an act of democracy, a right, duty, and obligation to us.

\section{The Second National Consultative Conference}

The ANC held a conference, the Second National Consultative Conference, in Zambia in June, 1985. The First National Consultative Conference was held in Morogoro, Tanzania, in 1969. Many decisions were adopted at this Second Conference, and the ANC is now in the process of implementing these decisions. We shall deal with those that have relevance to our topic: a future non-racial South Africa. The Conference endorsed the decision of the Morogoro Conference on the question of the leading role of the working class. Together with the other social forces, the role of the working class, at this particular moment, is to spearhead the struggle for national liberation, and not for socialism. This is all the more so because our struggle is not a civil rights struggle, it is not a struggle for the gradual assimilation of the Black majority into the White society. The Blacks cannot be absorbed into that society because the law

11. Id. at 55. 
forbids it. Civil rights, including the vote, are not for Blacks in South Africa. The constitution of the country ensures that. Therefore the struggle is for the transformation of the whole society. The struggle for national liberation remains at the top of our agenda.

At the Second National Consultative Conference, the ANC also decided to open its doors to all South Africans at every level. Whites, while not a nationally oppressed group, still suffer from the policies of apartheid. For instance, it is often said that the bantustans, as the centrepiece of "separate development," are "for" the Africans. But, of course, the bantustans are not truly separate or independent, in an economic or any other sense. The inflated salary of Kaiser Mantanzima of the Transkei, the most highly paid politician in South Africa, is very much connected with the fact that seventy-five percent of the Transkei budget consists of a grant from South Africa. In effect, the ordinary White taxpayer ends up helping to maintain the Transkei and subsidize Matanzima's salary. This is true of all other bantustans as well.

By taking this step of opening doors at all levels, the ANC was emphasising the simple fact that it has now assumed responsibility of being a leader not only of the Africans, but also of all the oppressed and democratic forces. That means the ANC is fighting for the national liberation of Blacks, especially the Africans, and the social emancipation of all South Africans, Black and White. The ANC has truly become a national organisation; an organisation of like-minded people, united by their common hatred of colonialism, racism, exploitation, and national degradation, and sharing a common goal. The ANC activities consist of propagating its own ideas amongst the people, mobilising them, and fighting in an constituency which the ANC defines: a nucleus of a future South African nation.

These activities are closely connected with the task of constantly clarifying the democratic content and essence of African nationalism so that it reflects the emergent nation-in-the-making. This means African nationalism has to take into consideration the different ethno-cultural groups which exist in South Africa, and this entails infusion of internationalism in our struggle. This becomes urgent if one considers that the regime has been constantly telling our people that it is "protecting" them from the ANC and by implication from the rest of humanity.

The future democracy in South Africa will definitely introduce a new approach to the politics of the country. The people, all people, all national groups, all colours will elect their representatives and spokespeople. No one will represent his "tribe," but the constitution will guarantee, 
in the spirit of the Freedom Charter, all national groups against national insults and humiliation.

This stems from the ANC's conviction that every people, despite its level of development, whether it has formed a nation or not, has a right to self-determination. In South Africa, the right to self-determination means the struggle for political liberation and social emancipation from apartheid, as well as the right to national self-determination of the different cultural linguistic groups under conditions of complete equality. National self-determination in South Africa does not mean territorial secession, separation, fragmentation, or formation of small States. It means the right of self-determination for a single South African nationto-be-born within the whole of South Africa. That means the destruction of the present state apparatus, and its replacement by a new one, one that states the right to self-determination. The right of the Blacks, and democratic Whites, to their own state power with sovereignty over every inch of South Africa must be guaranteed by this new state apparatus.

\section{Conclusion}

In South Africa, there is no evidence to suggest that there is any national group, African or not, which demands an existence separate and apart from the rest of the other South African national groups. There is no demand for a separate national culture. Nor is there a demand for separate education; on the contrary, the demand is for universal uniform education.

The most urgent task today is unity-the welding together of this vast human mass in the flux of a single grievance: the disability put upon them by law. That great mass is becoming mobile, learning to cooperate, and moving irresistibly forward to demand equality of opportunity and a state of their own creation. They are moving back to the Freedom Charter, and forward with the Freedom Charter.

South African experience demands the existence of a homogenous national movement which unites the heterogenous ethnic groups; a combined movement of all classes and groups consisting of the oppressed, including revolutionaries from the oppressor nation. The South African experience demands a movement that wages a national struggle primarily directed at the overthrow of political and legal discrimination-at the seizure of power. The ANC is definitely such a movement.

\section{AMANDLA NGAWTHU !}

POWER TO THE PEOPLE ! - say the masses of our people. 
Appendix: The Freedom Charter $\dagger$

\section{Preamble}

We, the people of South Africa, declare for all our country and the world to know:-

That South Africa belongs to all who live in it, black and white, and that no government can justly claim authority unless it is based on the will of the people;

That our people have been robbed of their birthright to land, liberty and peace by a form of government founded on injustice and inequality;

That our country will never be prosperous or free until all our people live in brotherhood, enjoying equal rights and opportunities;

That only a democratic state, based on the will of people can secure to all their birthright without distinction of colour, race, sex or belief;

And therefore, we, the people of South Africa, black and white, together-equals, countrymen and brothers-adopt this FREEDOM CHARTER. And we pledge ourselves to strive together, sparing nothing of our strength and courage, until the democratic changes here set out have been won.

\section{The People Shall Govern!}

Every man and woman shall have the right to vote for and stand as a candidate for all bodies which make laws.

All the people shall be entitled to take part in the administration of the country.

The rights of the people shall be the same regardless of race, colour or sex.

All bodies of minority rule, advisory boards, councils and authorities shall be replaced by democratic organs of self-government.

\section{All National Groups Shall Have Equal Rights!}

There shall be equal status in the bodies of state, in the courts and in the schools for all national groups and races;

All national groups shall be protected by law against insults to their race and national pride;

All people shall have equal rights to use their own language and to develop their own folk culture and customs; 
The preaching and practice of national, race or colour discrimination and contempt shall be a punishable crime;

All apartheid laws and practices shall be set aside;

The national wealth of our country, the heritage of all South Africans, shall be restored to the people;

The mineral wealth beneath the soil, the banks and monopoly industry shall be transferred to the ownership of the people as a whole;

All other industries and trade shall be controlled to assist the wellbeing of the people;

All people shall have equal rights to trade where they choose, to manufacture and to enter all trades, crafts and professions.

\section{The Land Shall Be Shared Among Those Who Work It!}

Restriction of land ownership on a racial basis shall be ended, and all the land re-divided amongst those who work it, to banish famine and land hunger;

The state shall help the peasants with implements, seed, tractors and dams to save the soil and assist the tillers;

Freedom of movement shall be guaranteed to all who work on the land;

All shall have the right to occupy land wherever they choose;

People shall not be robbed of their cattle, and forced labour and farm prisons shall be abolished.

\section{All Shall Be Equal Before the Law!}

No one shall be imprisoned, deported or restricted without a fair trial;

No one shall be condemned by the order of any Government official;

The courts shall be representative of all the people;

Imprisonment shall be only for serious crimes against the people, and shall aim at re-education, not vengeance;

The police force and army shall be open to all on an equal basis and shall be the helpers and protectors of the people;

All laws which discriminate on grounds of race, colour or belief shall be repealed.

\section{All Shall Enjoy Equal Human Rights!}

The law shall guarantee to all their right to speak, to organise, to meet together, to publish, to preach, to worship and to educate their children; The privacy of the house from police raids shall be protected by law; 
All shall be free to travel without restriction from countryside to town, from province to province, and from South Africa abroad;

Pass laws, permits and all other laws restricting these freedoms shall be abolished.

\section{There Shall Be Work and Security!}

All who work shall be free to form trade unions, to elect their officers and to make wage agreements with their employers;

The state shall recognise the right and duty of all to work, and to draw full unemployment benefits;

Men and women of all races shall receive equal pay for equal work;

There shall be a forty-hour working week, a national minimum wage, paid annual leave, and sick leave for all workers, and maternity leave on full pay for all working mothers;

Miners, domestic workers, farm workers and civil servants shall have the same rights as all others who work;

Child labour, compound labour, the tot system and contract labour shall be abolished.

\section{The Doors of Learning and of Culture Shall Be Opened!}

The government shall discover, develop and encourage national talent for the enhancement of our cultural life;

All the cultural treasures of mankind shall be open to all, by free exchange of books, ideas and contact with other lands;

The aim of education shall be to teach the youth to love their people and their culture, to honour human brotherhood, liberty and peace;

Education shall be free, compulsory, universal and equal for all children;

Higher education and technical training shall be opened to all by means of state allowances and scholarships awarded on the basis of merit;

Adult illiteracy shall be ended by a mass state education plan;

Teachers shall have all the rights of other citizens;

The colour bar in cultural life, in sport and in education shall be abolished.

\section{There Shall be Houses, Security and Comfort!}

All people shall have the right to live where they choose, to be decently housed, and to bring up their families in comfort and security;

Unused housing space shall be made available to the people; 
Rent and prices shall be lowered, food plentiful and no one shall go hungry;

A preventive health scheme shall be run by the state;

Free medical care and hospitalisation shall be provided for all, with special care for mothers and young children;

Slums shall be demolished, and new suburbs built where all have transport, roads, lighting, playing fields, creches and social centres;

The aged, the orphans, the disabled and the sick shall be cared for by the state;

Rest, leisure and recreation shall be the right of all;

Fenced locations and ghettoes shall be abolished, and laws which break up families shall be repealed.

\section{There Shall Be Peace and Friendship!}

South Africa shall be a fully independent state, which respects the rights and sovereignty of all nations;

South Africa shall strive to maintain world peace and the settlement of all international disputes by negotiation-not war;

Peace and friendship amongst all our people shall be secured by upholding the equal rights, opportunities and status of all;

The people of the protectorates-Basutoland, Bechuanaland and Swaziland-shall be free to decide for themselves their own future;

The right of all the peoples of Africa to independence and self-government shall be recognized, and shall be the basis of close cooperation.

Let all who love their people and their country now say, as we say here: "These freedoms we will fight for, side by side, throughout our lives, until we have won our liberty." 